1. はじめに

北炭幌内選炭工場に供される $+25 \mathrm{~mm}$ 粒度は重液選炭で選別し， 特塊, 特中塊, 特小塊を産出し $-25 \mathrm{~mm}$ の原炭はシク $(180 \mathrm{t} / \mathrm{h})$ 1 台で選別し, 市場の需要に対処していたが, 上級炭の需要増か ら, 56 年 7 月飞No. 2 ジク $(140 \mathrm{t} / \mathrm{h})$ を増設する時点で, 微粉 炭の回収と, 製品炭の脱水対策からスクリーンボール型遠心分離 機を 2 台設置し, 以来順調に運転管理されている。設置以後 3 年 間経過しているが，ての間の操業実績について解析し，遠心分離 機を設置するととによつて,メーンシックナの操業変化につけて 合わせて報告する。

\section{2. 粉炭の需要推移}

第 1 図に最近の製品炭（粉炭）の産出割合の推移を月間の出炭 と対比して示した。

\section{$2 \cdot 1$ 遠心分離機の設置個所}

当選炭工場のフローシートと, 遠心分離機の設置個所を第 2 図 に示した。

\section{$2 \cdot 2$ 遠心分離機の構造と諸元}

構造は第 3 図に示し，諸元を第 1 表に示した。

\section{$2 \cdot 3$ 遠心分離機のフィード方法の变更}

設置当初は $300 \phi$ サイクロンアンダーを自動弁で調整されて, フィードされていたが, 要部のセラミックタイルと取替工事の時 点で, $3 \mathrm{~mm}$ のシーブベンドを自動弁の前に取付け, シーブベン ドのアンダーをフィードするように改造した。またオーバサイズ
はスクリーンで回収している。

\section{$2 \cdot 4$ 遠心分離機の産出物之排水中固形物の粉度分布}

産出物と排水中の固形物の粒度分布を第 4 図に示した。図中の 選炭大会発表の Dat a ${ }^{1)}$ はシーブベンドでカットしない時の粒度分 布であり，また59年6月1日現在のData は $3 \mathrm{~mm}$ シープベンドで カットした原液を遠心分離機で脱水後の産物の粒度分布である。

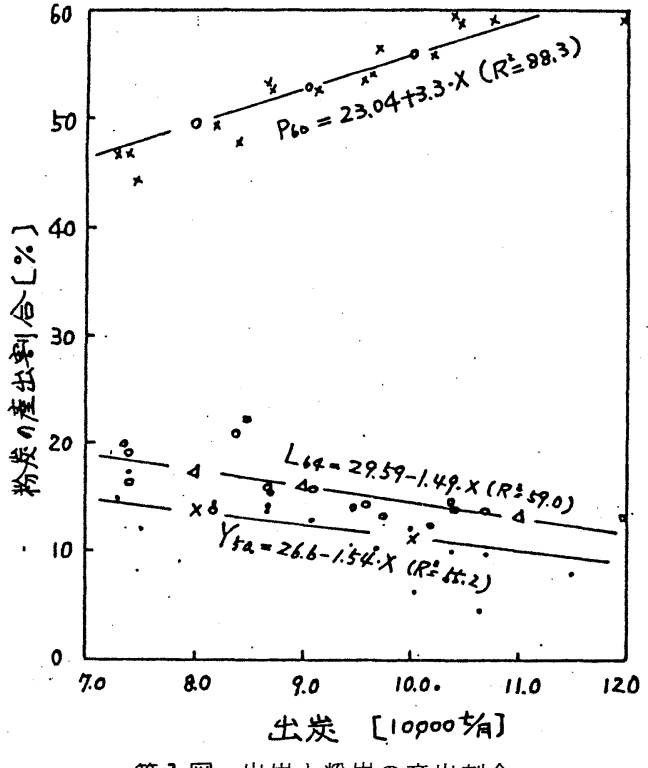

第 1 図出炭と粉炭の産出割合

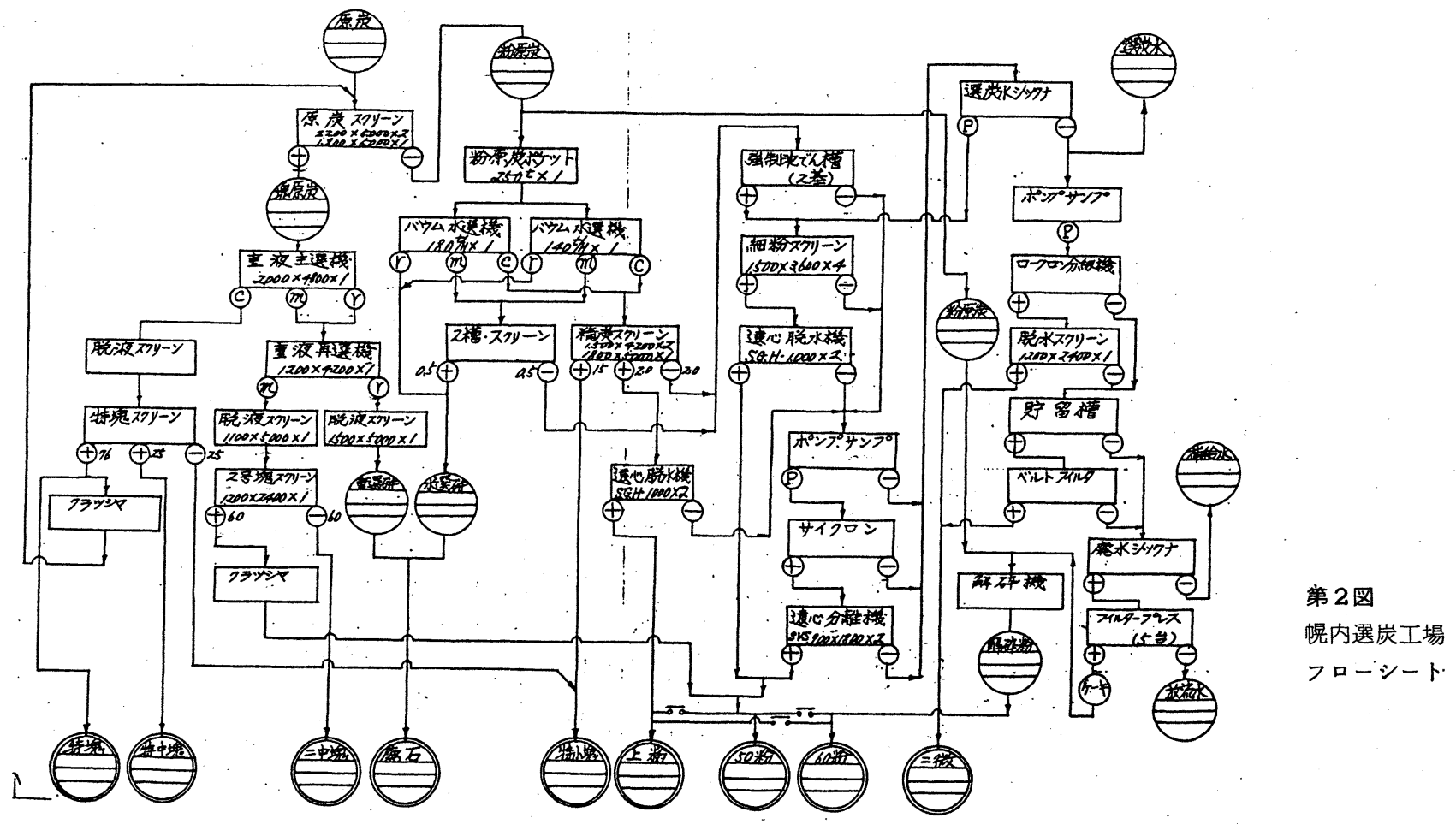

$818<46>$ 
第 1 表 遠心分離機の諸元

\begin{tabular}{|c|c|}
\hline 形 式 & $\begin{array}{l}\text { スクリーンボール型 } \\
\text { SVS } 900 \times 1,800\end{array}$ \\
\hline 処 理 量 & $16.8 \mathrm{t} / \mathrm{h}$ \\
\hline 電 動 機 & $160 \times 4 \mathrm{PW} \times 3,000 \times 50^{\mathrm{C} / \mathrm{s}} \times 3$ 相 \\
\hline 給油ポンプ & $0.2^{\mathrm{kW}} \times 4 \mathrm{P} \times 200^{\mathrm{V}} \times 50^{\mathrm{c} / \mathrm{s}} \times 3$ 相 \\
\hline $\begin{array}{l}\text { ポール回転数 } \\
\text { 遠 心 効果 }\end{array}$ & $\begin{array}{l}740 \mathrm{rpm} \\
276 \mathrm{G}\end{array}$ \\
\hline 回転速度差 & $1 / 40$ \\
\hline
\end{tabular}

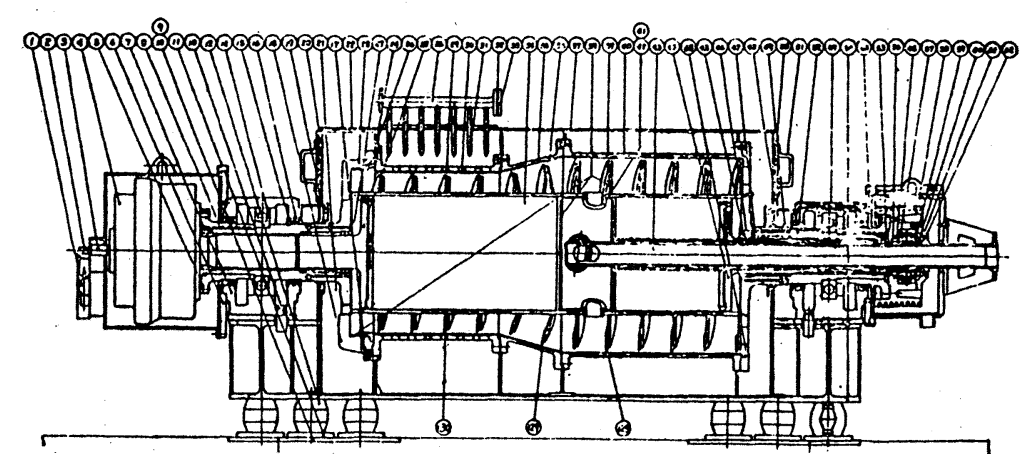



第 4 図 遠心分離機の産物と排水固形物の粒度分布

この粒度分布から，沈降の速い微粉炭はNNo.2分離機にフィードさ れている傾向がある。また粒度分布の差はフィード側の立型ポン プの据付位置の差のようである。

\section{3. ジグ運転時間による分離機とメーンシックナの操業状態}

遠心分離機の操業はシグの運転時間と関係していると考えられ るので, 分離機の灰分濃縮度関係を求好期間（57 年11月 1 日 〜 11 月 30 日) におけるジクの運転状態と, メーンシックナの操 業状態を調べた。
第3図分離機の構造

\section{$3 \cdot 1$ ジグの運転状態}

ジグの運転状態のData は第 2 表に平均值で示した。

運転管理の安定性を判断する目標として,X軸には〔（2槽灰

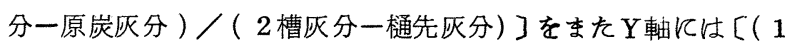
槽灰分一原炭灰分 $) /(1$ 槽灰分一原炭灰分）]を取 b, No.1， No. 2 シグについての関係を求めた結果を第 5,6 図に示した。

乙の結果№.2, ジグの方が $R^{2}$ 值の低い結果を得ている。乙の 原因は第 3 表から No. 1 ジグの平均運転時間は, $14^{\circ} 20^{\prime}$ と No.2 ジグの時間は $9^{\circ} 15^{\prime}$ となていた。ての運転時間の差, すなわち, 欠炭時間の長短および欠炭の回数の多少によるすのと考えられる。

第 2 表 バウムジグ運転状態（平均值）

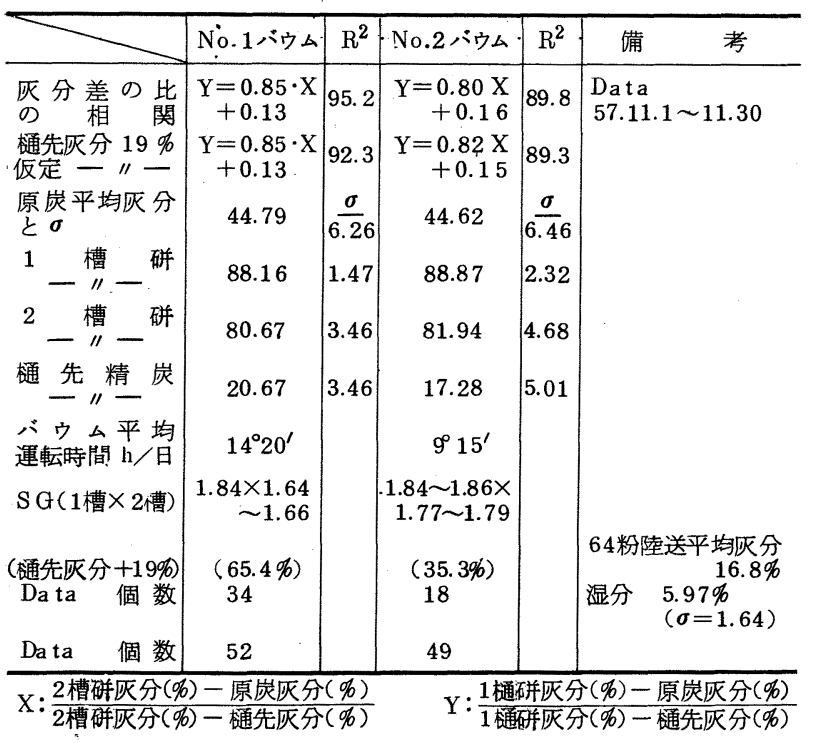

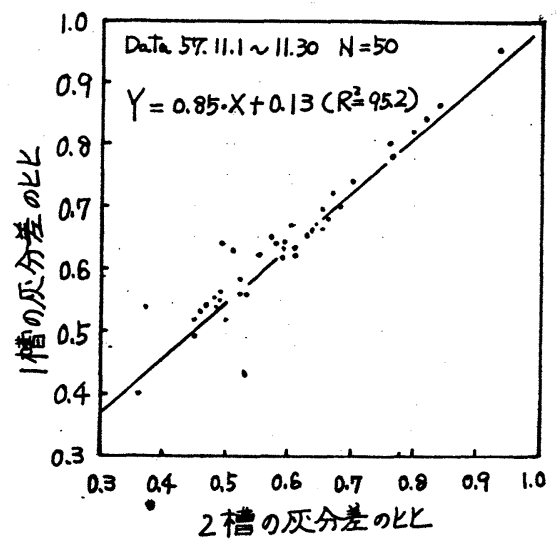

第 5 図

No. 1 シグの 2 槽と 1 槽 の灰分差の比の関係

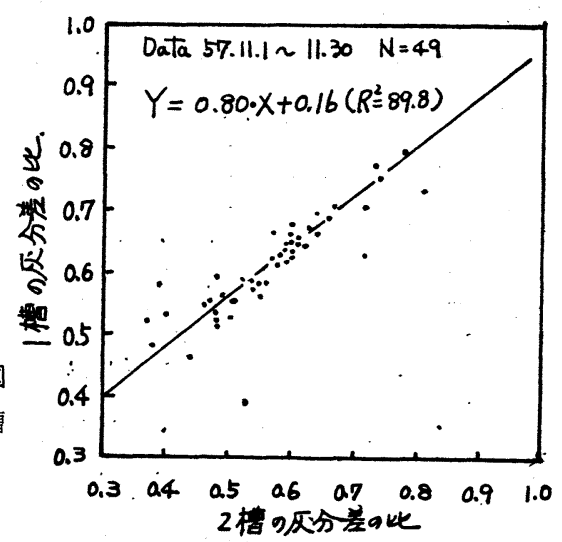


第3表 メーンシックナ，遠心分離機データ

\begin{tabular}{|c|c|c|c|c|}
\hline \multicolumn{2}{|c|}{ メーンシックナ } & \multicolumn{3}{|c|}{ No. 1 , No. 2 遠心分離機 } \\
\hline 測 定 個 所 & 平均值 & 測 定 個 所 & No.1 & No. 2 \\
\hline $\begin{array}{c}フ ィ-ト ゙ \text { 灰分 } \\
A_{\mathrm{f}}\end{array}$ & $\left(\begin{array}{c}3.85 \\
58.71\end{array}\right)$ & $\begin{array}{c}フ ィ-ト ゙ \text { 灰分 } \\
A_{f}\end{array}$ & 41.5 & 40.9 \\
\hline 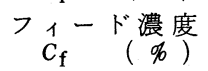 & $\left(\begin{array}{l}0.82) \\
7.43\end{array}\right.$ & $-{ }_{\sigma}^{\prime \prime}-$ & 2.77 & 3.65 \\
\hline $\begin{array}{c}\text { スピゴット灰分 } \\
A_{\mathrm{S}}(\%)\end{array}$ & $\begin{array}{c}\left(\begin{array}{r}5.99 \\
43.04\end{array}\right) \\
0\end{array}$ & $\begin{array}{c}\text { 脱 水炭 灰 } \\
\text { (精炭) \% }\end{array}$ & 33.8 & 34.1 \\
\hline$-C_{\mathrm{s}}{ }^{\prime \prime}$ - $\left(\begin{array}{c}\text { 濃度 } \\
\text { \% })\end{array}\right.$ & $\left(\begin{array}{c}(3.62) \\
15.76\end{array}\right)$ & $-{ }_{\sigma}^{\prime \prime}-$ & 3.19 & 3.45 \\
\hline $\begin{array}{c}\text { オーバ一灰分 } \\
A_{\mathrm{O}} \quad(\%)\end{array}$ & $\left(\begin{array}{l}(61.84 \\
)\end{array}\right.$ & $\begin{array}{l}\text { 排水固形物 } 9 \\
\text { 分 }(\mathrm{Ao})(\%)\end{array}$ & 64.8 & 63.1 \\
\hline$-C_{\mathrm{o}}{ }^{\prime \prime}\left(\begin{array}{c}\text { 濃度 } \\
\%)\end{array}\right.$ & $\left(\begin{array}{l}\left(\begin{array}{l} \\
6.98\end{array}\right) \\
\mid\end{array}\right.$ & $-\quad " \prime$ & 3.75 & 2.31 \\
\hline$A_{\mathrm{f} / A_{\mathrm{s}}} \quad\left(\begin{array}{l}\sigma \\
\end{array}\right.$ & $\left(\begin{array}{c}(0.140) \\
1.382\end{array}\right.$ & $A_{\mathrm{f}} / A_{\mathrm{S}}$ & 1.233 & 1.206 \\
\hline$A_{0} / A_{\mathrm{s}}(-" /-)$ & $\begin{array}{c}(0.196) \\
1.462\end{array}$ & $A_{0} / A_{\mathrm{S}}$ & 1.932 & 1.872 \\
\hline$C_{\mathrm{f} / C_{\mathrm{s}}^{\prime}}(-" 1-)$ & $\cdot\left(\begin{array}{c}0.122) \\
0.51\end{array}\right.$ & 標 準 $\left\{A_{\mathrm{f}} / A_{\mathrm{s}}\right.$ & 0.099 & 0.111 \\
\hline$C_{0} / C_{\mathrm{s}}{ }^{(-\prime \prime-)}$ & $\begin{array}{c}(0.137) \\
0.483\end{array}$ & $(\sigma)^{\mathrm{E}}\left\{A_{\mathrm{O}} / A_{\mathrm{s}}\right.$ & 0.222 & 0.208 \\
\hline Data $N$ & 9 & Data $N$ & 24 & \\
\hline $\begin{array}{l}\text { Data サンプリ } \\
\text { ング期間 }\end{array}$ & $\begin{array}{c}58.11 .1 \\
\sim 11.30\end{array}$ & $\begin{array}{l}\text { Data サンプリ } \\
\text { ング期間 }\end{array}$ & $\mid \begin{array}{c}58.11 .1 \\
\sim 11.30\end{array}$ & $\begin{array}{c}58.11 .1 \\
\sim 11.30\end{array}$ \\
\hline
\end{tabular}

ジグの運転と休止の繰返しがジグの成層飞影響を与え，その結 果第 5 図と第 6 図のData 亿影響を与える一因と考えられる。 た欠炭時間とその回収は No. 2 ジグの方が多かつたので，その分 $\mathrm{No} .2$ シグの $\mathrm{R}^{2}$ 値の低い要因と考えられる。

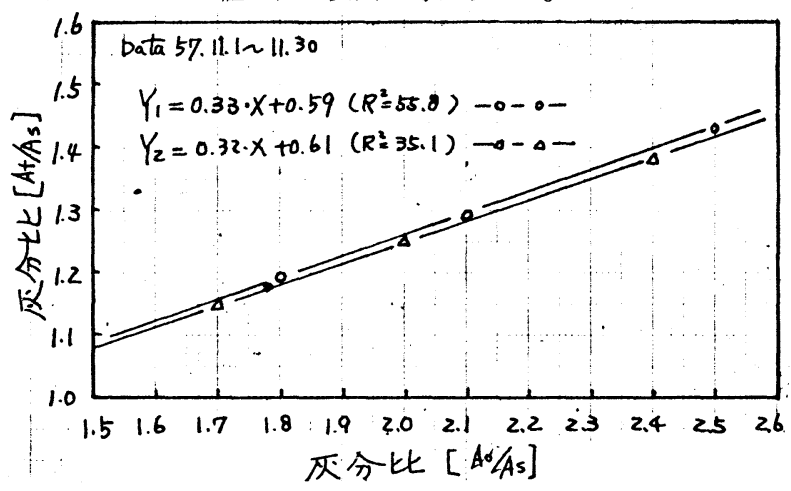

第 7 図 No.1，No.2 遠心分離機の灰分についての濃縮度相関



第 7-A図

遠心分離機の灰 分差の比の関係

\section{$3 \cdot 2$ 遠心分離機の操業状態}

3 ・1 項のシグ運転下における遠心分離機の灰分比の相関関係 を求めたのが第 7 図である。

ての結果 $\mathrm{R}^{2}$ 值の低値を得ている。乙の原因はシク運転の影響 も一つの要因と考えられ, 分離機内での帯留時間が短かいため,

フィード側の条件に敏感に影響されるるのと考えられる。第 3 表 亿平均值の Data を示し, 灰分差の比の関係は第 7 -A図に示す。 $3 \cdot 3 \times$ メンシックナの操業状態

乙の解析期間（ 57 年 11 月）飞おけるメーンシックナの灰分お よび濃度についての相関関係を調べた結果を第 8,9 図に示す (Dat a 数 9 個)。

\section{4. 遠心分離機運転後のメーンシックナの操業状態}

前節での Data は 9 個であつて, 関係を求めるには不足である と考元て, 分離機運転後の Data 67 個 ( 58 年 5 月 59 年 4 月) について解析するとととし, 解析方法は灭分比の相関 ${ }^{2)}$, 濃度比 の相関〔フィード濃度 $(C f)$ /スピゴット濃度 $(C s)$ : (オーバ 一濃度 $\left(C_{0}\right) /$ スピゴット濃度 $\left(C_{s}\right)$ ]と灰分の比の相関につい て調べた。

灰分比については第 10 図, 濃度比については第 11 図, また灰 分差の比の相関 ${ }^{3)}$ については第 12 図に示した。また第 10 図と第 11 図には分離機設置前の相関式も入れた。

分離機によつて微粉炭が回収されることによつて、メーンシッ クナにフィードされる微粉炭の量が減少したため灰分の濃縮度は 上昇し, 濃度についての濃縮度は低下し, 灰分差の相関関係から も,より安定した操業状態となつた。以上の結果からメーンシッ クナから抜を出すスラリーポンプは設置前の 2 台運転から 1 台運 転で間に合らよらになり，運転時間も短時間ですむようになつた。 をたシックナの容積が大きいてとから久炭時によつて受ける影 響は分離機之異なり，時間がかかるように考えられる。第 4 表に 分離機設置前後のシックナの変化をまとめた。

\section{5. 遠心分離機の回収率}

実機運転時の回収率の算出は濃度から求め, Data は 58 年 5 月 $\sim 59$ 年 4 月の分析值を用い，結果は第 13 図に示した。

回収率が大幅に低下していたData るあり，一応回収率 $80 \%$ 以 上のDataの平均值は $83.8 \%$ あつた。

この回収率は一昨年発表した時と同じ結果となり，運転開始以 後 3 年経過後の回収率は低下していないるのと考える。李回収 率についてはNo.1分離機のるのである。

回収率が大幅に低下している時の原因を調べたら，2台のジク

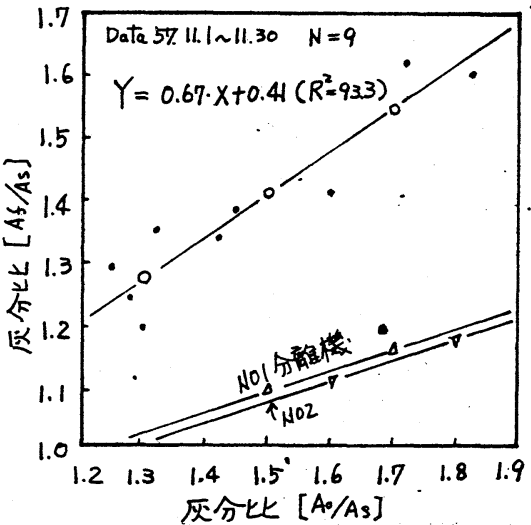

第8図メーンシックナの扊分比の関係

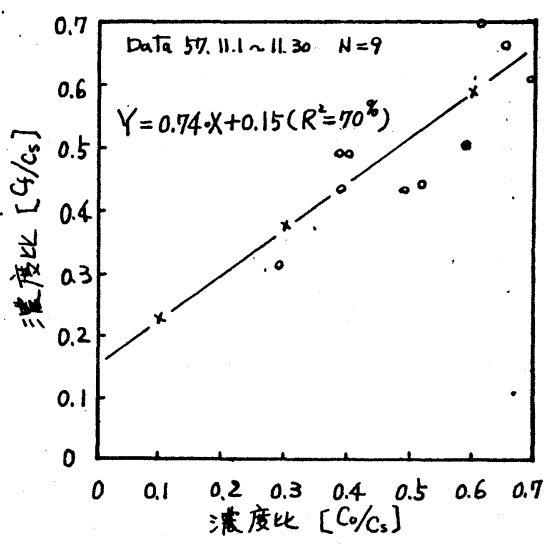

第 9 図メーンシックナの濃度比の関係 

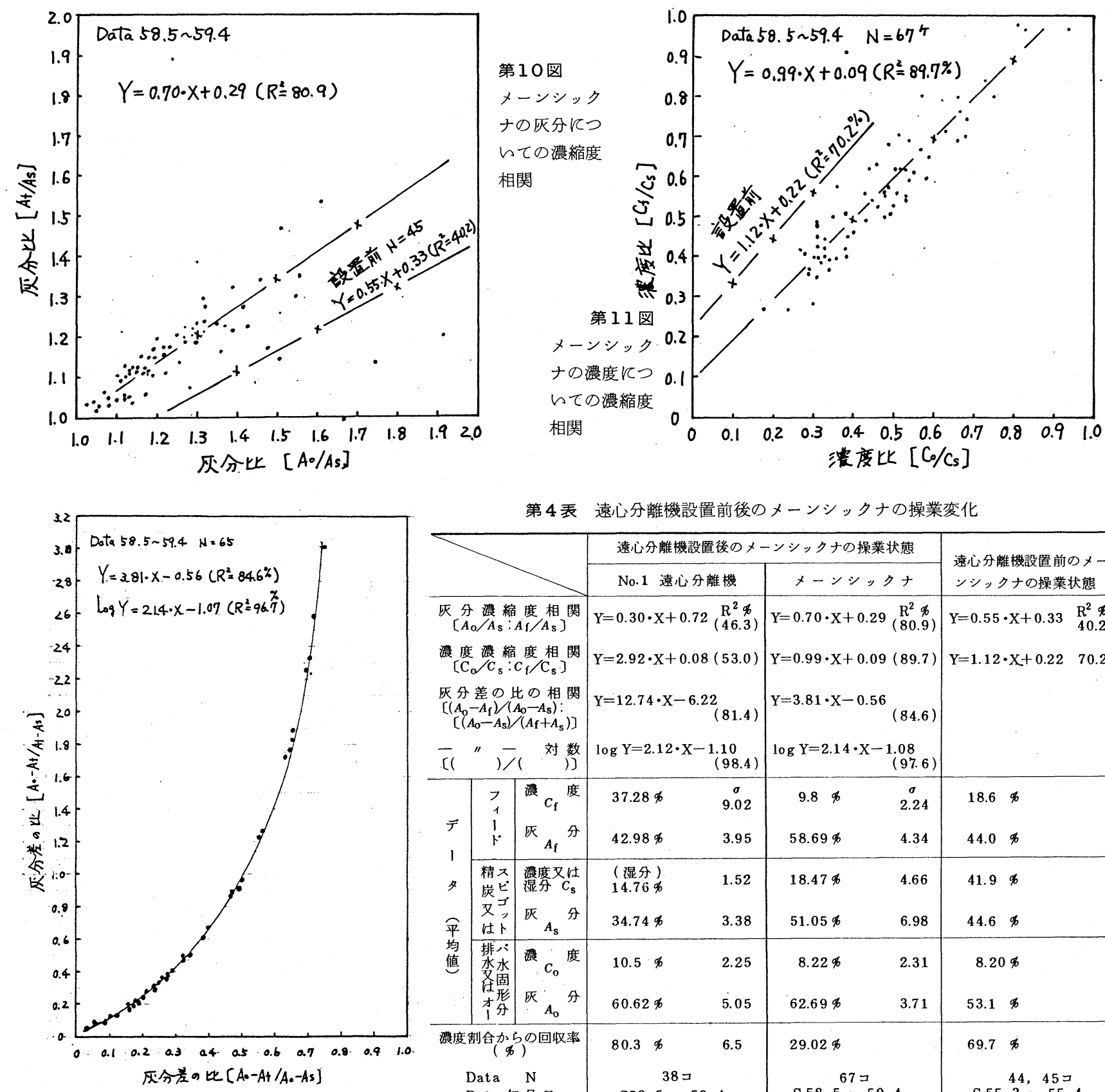

第 4 㞷 遠心分離機設置前後のメーンシックナの操業変化

\begin{tabular}{|c|c|c|c|c|c|c|c|}
\hline & \multicolumn{4}{|c|}{ 遠心分離機設置後のメーンシックナの操業状態 } & \multirow{2}{*}{$\begin{array}{l}\text { 遠心分離機設畳前のメ- } \\
\text { ンシックナの操業状態 }\end{array}$} \\
\hline & & & \multicolumn{2}{|c|}{ No.1 遠心分離機 } & \multicolumn{2}{|c|}{ メーンシックナ } & \\
\hline \multicolumn{3}{|c|}{$\begin{array}{c}\text { 灰分㵙縮度相関 } \\
{\left[A_{\mathrm{o}} / A_{\mathrm{s}}: A_{\mathrm{f}} / A_{\mathrm{s}}\right]}\end{array}$} & \multicolumn{2}{|c|}{$\mathrm{Y}=0.30 \cdot \mathrm{X}+0.72 \stackrel{\mathrm{R}^{2} \phi}{46.3)}$} & \multicolumn{2}{|c|}{$\mathrm{Y}=0.70 \cdot \mathrm{X}+0.29 \stackrel{\mathrm{R}^{2} \not \not}{(80.9)}$} & $\mathrm{Y}=0.55 \cdot \mathrm{X}+0.33 \quad \mathrm{R}^{2} \%$ \\
\hline \multicolumn{3}{|c|}{ 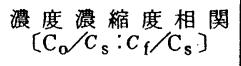 } & \multicolumn{2}{|c|}{$Y=2.92 \cdot X+0.08(53.0)$} & \multicolumn{2}{|c|}{$Y=0.99 \cdot X+0.09(89.7)$} & \multirow[t]{2}{*}{$\mathrm{Y}=1.12 \cdot \mathrm{X}+0.22 \quad 70.2$} \\
\hline \multicolumn{3}{|c|}{$\begin{array}{c}\text { 灭分美の比の相関 } \\
{\left[\left(A_{0}-A_{\mathrm{f}}\right) /\left(A_{0}-A_{\mathrm{s}}\right):\right.} \\
{\left[\left(A_{0}-A_{\mathrm{s}}\right) /\left(A_{\mathbf{f}}+A_{\mathrm{s}}\right)\right]}\end{array}$} & \multicolumn{2}{|c|}{$\mathrm{Y}=12.74 \cdot \mathrm{X}-6.22(81.4)$} & \multicolumn{2}{|c|}{$\mathrm{Y}=3.81 \cdot \mathrm{X}-0.56$} & \\
\hline \multicolumn{3}{|c|}{ 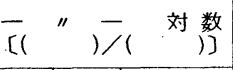 } & \multicolumn{2}{|c|}{$\log Y=2.12 \cdot X-1.10$} & \multicolumn{2}{|c|}{$\log Y=2.14 \cdot X-1.08$} & \\
\hline \multirow{3}{*}{$\begin{array}{l}\widetilde{\mathcal{T}} \\
1 \\
\text { 夕 }\end{array}$} & & ${ }^{(\text {滣 }} C_{\mathrm{f}}$ 度 & $37.28 \%$ & $\begin{array}{c}\sigma \\
9.02\end{array}$ & $9.8 \%$ & $\begin{array}{c}\sigma \\
2.24\end{array}$ & $18.6 \%$ \\
\hline & & 灰 ${ }_{A_{\mathrm{f}}}$ 分 & $42.98 \not$ & 3.95 & 58.69 \% & 4.34 & $44.0 \%$ \\
\hline & 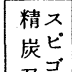 & 嚗麿又は $C_{\mathrm{s}}$ & $\begin{array}{l}\text { (湿分) } \\
14.76 \%\end{array}$ & 1.52 & $18.47 \%$ & 4.66 & $41.9 \not$ \\
\hline & & 灰 ${ }_{A_{\mathrm{S}}}$ 分 & $34.74 \varnothing$ & 3.38 & $51.05 \%$ & 6.98 & \\
\hline & $\begin{array}{l}\text { 排: } \\
\text { 永永 } \\
\end{array}$ & 濃 ${ }_{c_{\mathrm{o}}}^{\text {度 }}$ & $10.5 \%$ & 2.25 & $8.22 \%$ & 2.31 & $8.20 \%$ \\
\hline & & 灰 & $60.62 \%$ & 5.05 & $62.69 \%$ & 3.71 & $53.1 \%$ \\
\hline \multicolumn{3}{|c|}{ 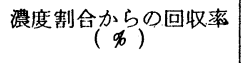 } & $80.3 \%$ & 6.5 & $29.02 \%$ & & 69.7 क \\
\hline \multicolumn{3}{|c|}{$\begin{array}{l}\text { Data } N \\
\text { Data 年月 日 }\end{array}$} & \multicolumn{2}{|c|}{$\begin{array}{c}38 \sqsupset \\
\text { S58. } 5 \sim 59.4 \\
\end{array}$} & \multicolumn{2}{|c|}{$\begin{array}{c}67 \beth \\
\text { S } 58.5 \sim 59.4 \\
\end{array}$} & $\begin{array}{c}44,45 \sqsupset \\
\text { S 55. } 3 \sim 55.4\end{array}$ \\
\hline
\end{tabular}

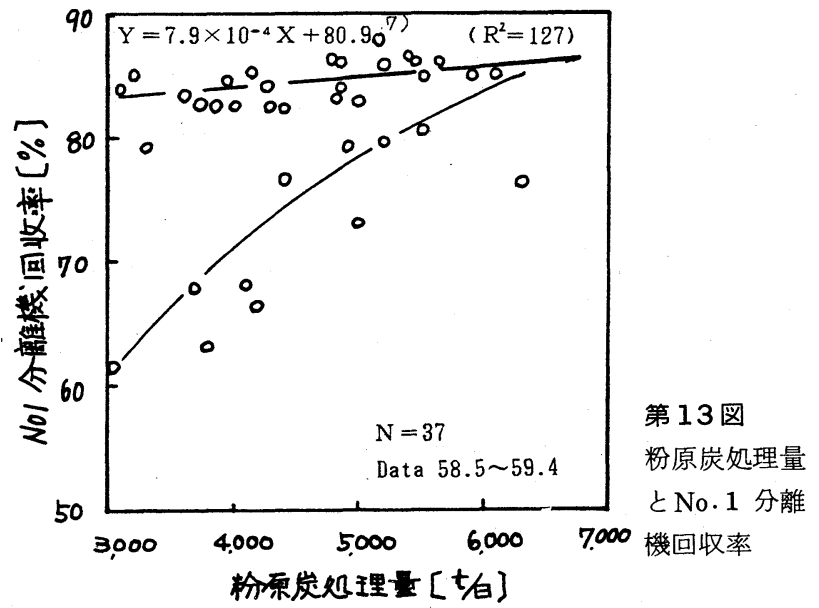

のらちいずれか 1 台欠炭で停止していた時のDataであるてとが 分つた。すなわち, ジグ 1 台運転では分離機へフィードされる微 粉炭量は少なく, No.2 分離機 1 台で回収されていて, No.1 分離機 へフィードされるスラリー中に回収可能な微粉炭量が少ないもの と考えられる。乙の結果としてNo.1 分離機の回收率は低下する るのと考えられる。

$5 \cdot 1$ 回収率変動の要因

第 13 図には粉原炭 (水選原炭)の 1 日当りのジの处理 $\mathrm{t}$ 数と No.1 分離機の回収率の関係を求めたものであるが, 粉原炭処理 も $\mathrm{t}$ 数が多くなればNo.1 分離機の回収率は上向をの傾向があり， 逆に処理 $\mathrm{t}$ 数が下がれば回収率は低下の傾向がある。

この原因はジグの運転時間とNo.1, No.2 シグの欠炭時間と回 数に密接に関係しているようである。

ジグ炭停止の要因は種々あつて, 欠炭時間と回数は日々の 運転状況によつて変動する。 


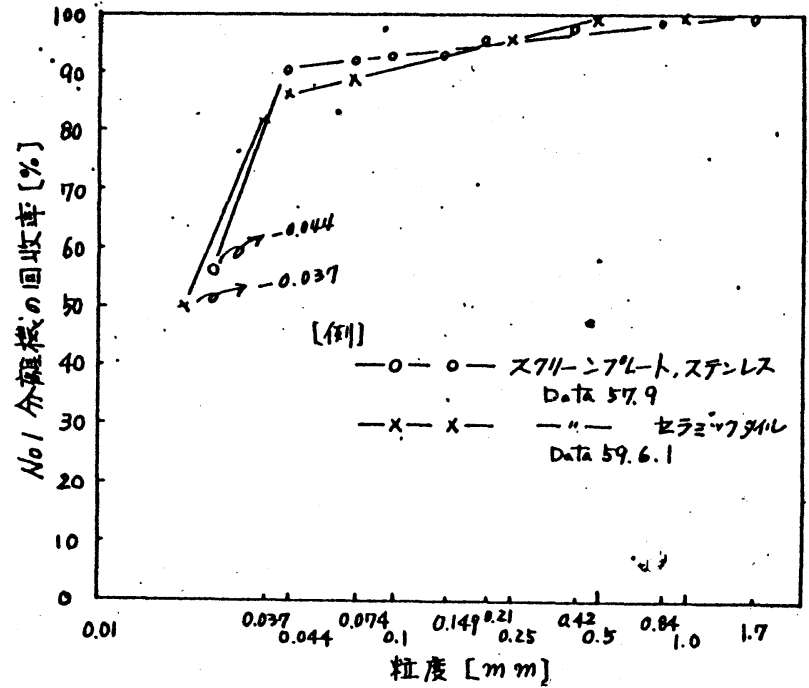

第14図 No.1 遠心分離機の粒度別回収率

\section{$5 \cdot 2$ 粒度別回収率変動の要因}

第 14 図に分離機の正常運転の粒度別回収率と設置後 3 年経過後 の回収率の割合を示した。設置当初, 分離機の要部はステンレス硬 化品であつたが，今日では要部セラミックタイルを使用している。 スクリーンプレートにステンレスを使用した時とセラミックタ イルを使用したとさでは, 回収率に若干の差があるようである。 すなわち, 同じ回収率でもスクリンプレートイステンレスを使用 した時には $0.1 \sim 0.044 \mathrm{~mm}$ 粒度範囲での回収率は高く, 逆に七 ラミックタイル使用時はこの粒度範囲の回収率は下がる傾向があ る。しかしその回収率の差は少ない。

\section{$5 \cdot 3$ 遠心分離機設置の効果}

分離機設置の目的苮粉炭の回収と製品炭の湿分の低下であつ たが，ての目的は充分達成されている。

その効果を列記すると

(1) 微粉炭の湿分減少により, 製品炭全体の湿分の減少と, 湿 分低下によるペナルテーの減少

(2) ヘルトフィルタで回収微粉炭の減少による混炭経費の大幅 な節約

(3) 微粉炭の時間当りの回収量が増加したため選炭時間の大幅 な短縮

(4) メーンシックナが軽負荷運転となり, 運転時間の短縮（2 $\sim 2.5 \mathrm{~h} /$ 日)

(5) スピゴットポンプは 2 台から 1 台運転となり，ポンプ寿命 が 8〜12 カ月にのびたととによる修理費の節約

\section{6. 遠心分離機の保守}

分離機を設置する時点で摩耗個所および耐久時間が，どの程度 か明らかでなかつたので, 最初はステンレス硬化材をスクリーン プレート等に使用した。

スクリーンプレートとスキマーの点検は, 毎週 3 方土曜日運転 停止の時点で, 内部水洗い後マンホールから目視で摩耗状態の点 検を行なつた。ての点検方法は今日も続行している。

スクリーンプレート点検を継続しながら，実運転時間 1,200〜 1,300 時間の時点で分解整備に入つた。

ステンレス硬化材では, 耐摩耗性に弱いと判断して, 要部 ( ス クリーンブレート, ボールコーン, スクリューetc）飞，七ラミックタイ ルを張付けるととるに，分離機へフィードする微粉炭に比較的粒子

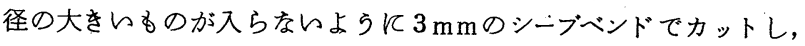
このシープベンドのアンダーをフィードするよらにした結果, 自動
弁の閉塞によるトラブルの発生るなくなり,タイル張付部の摩耗 る减少し, 現在では寿命は 6,800 9,000 時間にのびている。 スキマーの寿命は使用する材質によつて異なるが，約 1,100〜 1,200 時間で取替えている。

自動弁はゴムライニングとなつているが，てのゴムライニンク の寿命は約 5,000時間である。分離機のフィードスラリーポンプ は, 実運転時間 $2,400 \sim 3,500$ 時間で, 不良部品の取替えを行な つている。運転保守管理の実績を第 5 表にをとめた。

第 5 表 遠心分離機保守管理表

\begin{tabular}{|c|c|c|}
\hline & 実動時間 (h) & 補 修 個 \\
\hline 遠 & $1,200 \sim 1,300$ & $\begin{array}{l}\text { スクリーンプレート }(\max 1,800 \mathrm{~h}) \\
\text { ボールコーン, スクリューコンベヤ, 各セラミック化 }\end{array}$ \\
\hline 心 & $4,500 \sim 6,100$ & スクリューコンベヤタイル補修 \\
\hline 分 & $6,700 \sim 9,000$ & $\begin{array}{l}\text { スクリーンセラミック,スクリュータイル補修 } \\
\text { No.2号スクリューコンベヤ取替え }\end{array}$ \\
\hline 機 & $1,100 \sim 2,000$ & スキマー取替え \\
\hline 公 & $5,100 \sim 6,100$ & ダイヤフラムバルブ取替え \\
\hline サ & 4,400 & 鉄製ノズル使用不能 \\
\hline $\begin{array}{l}\text { イ } \\
\text { ク }\end{array}$ & $8,200 \sim$ & ノズル セラミック 1〜2 $\mathrm{mm}$ の摩耗, 使用中 \\
\hline 口 & $3,200 \sim 4,200$ & 鉄製サイクロン本体修理使用不能 \\
\hline ע & $5,200 \sim 5,700$ & 鋳物製 $1 \sim 2 \mathrm{~mm}$ の摩耗, 使用中 \\
\hline
\end{tabular}

7. 終りに

遠心分離機を 2 台設置したととにょり，微粉炭の回収は設置前 より大幅に改善されたが, 分離機の回収率はかなり変動している ことも分かつた。この原因はフィード側に微粉炭量の変動の要因 があるてと, 寸なわち, ジグの給炭量の変動と欠炭停止による影 響を受けるととと, 立型ポンプの据付位置によつて, 回収される 粒子の分布はNo.1，No.2，分離機では若干の差が出てくる。

メーンシックナに, フィードされている固形物の灰分は設置前 より, $8 \%$ 程度上昇し, 廃水の最終処理工程で回収されるプレス ケーキの灰分る $8 \sim 9 \%$ 上昇している。

分離機設置による効果で特に大きいのは脱水効果であり, 製品 炭の湿分は安定した值となつている。

また微粉炭の脱水処理が可能となつた今日では, 製品炭の全粒 度脱水体制が整つたことになり, より安定した湿分の製品炭を維 持するよら心がけている。

分離機の要部セラミック化によつて実運転時間が大幅にのびた てとにより, 補修時間の減少と混炭経費の節減に寄与している。

分離機の解析にあたつては操業が安定してくると, サンプリン グの回数と, 1 回当りのサンプリング時間がのびたため, 短時間 で必要な Dataは日常運転管理のために分析されている現場分析 值に基づけて行なつた。したがつて多少のDataのバラッキや信 頼性飞欠ける分析值もあつたため, Data 数を増加して解析した。

今後もよりいつそう安定した品位の製品炭を産出するように努 力する所存である。諸先輩ので指導を願えれば幸である。

\section{参 考 文 献}

1）館脇·中沢：日本釷業会誌，98 [ 1134$] ， 818 \sim 825$ ，(1982）

2）館脇·佐藤：炭砿技術誌，10，9，(1982）

3）佐藤：炭矿技術誌，2，13，(1983）

3）佐藤：炭吰技術誌，11，11，(1983） 